\title{
Carbon dioxide balance assessment of the city of Florence (Italy), and implications for urban planning
}

\author{
Francesco Primo Vaccari ${ }^{\mathrm{a}, *}$, Beniamino Gioli ${ }^{\mathrm{a}}$, Piero Toscano ${ }^{\mathrm{a}, \mathrm{c}}$, Camilla Perrone $^{\mathrm{b}}$ \\ a Institute of Biometeorology (IBIMET), National Research Council (CNR), Via G. Caproni, 8, 50145 Florence, Italy \\ ${ }^{\mathrm{b}}$ Department of Urban and Regional Planning (DUPT), University of Florence, Via P.A. Micheli, 2, 50121 Florence, Italy \\ ' Department of Agricultural and Environmental Sciences, University of Udine, Via delle Scienze, 206, 33100 Udine, Italy
}

\section{H I G H L I G H T S}

- Florence's green areas offset $\mathrm{CO}_{2}$ emissions from $2.6 \%$ (winter) to $16.9 \%$ (spring).

- Spatially $\mathrm{CO}_{2}$ emissions decrease by $92 \%$ along an urban to rural landscape.

- Carbon dioxide balance provides innovative information tool for urban planning.

\section{A R T I C L E I N F O}

\section{Article history:}

Received 9 August 2012

Received in revised form 9 August 2013

Accepted 10 August 2013

\section{Keywords:}

Carbon dioxide fluxes

Eddy covariance

Urban design

Urban transect

\begin{abstract}
A B S T R A C T
The carbon dioxide balance for the Municipality of Florence $\left(102.3 \mathrm{~km}^{2}\right)$, with $29.1 \mathrm{~km}^{2}$ of green space within the built-up city and $46.6 \mathrm{~km}^{2}$ in the semi-rural peri-urban area, shows that collectively the green spaces offset $6.2 \%$ of the direct carbon emissions. However the green spaces in the densely built-up city only offset $1.1 \%$ of the emissions. $13.5 \mathrm{ktCO}_{2} \mathrm{y}^{-1}$ are taken up by vegetation in the built-up areas and $58.7 \mathrm{ktCO}_{2} \mathrm{y}^{-1}$ by vegetation in the peri-urban area. Urban green spaces are most efficient in offsetting anthropogenic $\mathrm{CO}_{2}$ emissions during the period March to June when plant growth rates are high and emission rates are relatively low. Landscape fragmentation is highly positively correlated with total $\mathrm{CO}_{2}$ emissions and negatively correlated with $\mathrm{CO}_{2}$ uptake. The detailed information produced during this investigation shows that policies aimed at reducing $\mathrm{CO}_{2}$ emissions in winter months will have a greater overall effect on total $\mathrm{CO}_{2}$ release to the atmosphere than those aimed at increasing $\mathrm{CO}_{2}$ uptake. Nevertheless, urban designers should consider all the benefits of urban green spaces and seek to ensure that new suburban development conserves green spaces and aims at sustainable urban design.
\end{abstract}

(C) 2013 Elsevier B.V. All rights reserved.

\section{Introduction}

Urban areas, defined as densely developed residential, commercial and other non-residential areas, cover a minute portion of the Earth's land surface ( $<3 \%$ ), but host more than $50 \%$ of the population (CIESIN, 2004), thus contributing significantly to global anthropogenic emissions of greenhouse gases (GHG) to the atmosphere (Dhakal, 2010). To mitigate such emissions, several strategies aimed at improving the urban environment ecological performance have been proposed and adopted during the past decade: improving the energy efficiency of buildings (Aydin \& Cukur, 2012); reducing road traffic (Reckien, Ewald, Edenhofer, \& Ludeke, 2007); managing and designing existing and new urban green spaces (Pataki et al., 2011).

\footnotetext{
* Corresponding author. Tel.: +39055 3033711; fax: +39055 308910. E-mail addresses: f.vaccari@ibimet.cnr.it (F.P. Vaccari), b.gioli@ibimet.cnr.it (B.Gioli), p.toscano@ibimet.cnr.it(P.Toscano), camilla.perrone@unifi.it(C. Perrone).
}

The role of urban green spaces, defined as all areas covered by lawns, shrubs and trees, in highly human altered ecosystems, is well recognized (Dobbs, Escobedo, \& Zipperer, 2011). There is a significant amount of scientific literature underlining the benefits of urban green spaces in reducing the urban heat island by creating a cooling effect (Hu \& Gensuo, 2010; Ng, Chen, Wang, \& Yuan, 2012; Oliveira, Andrade, \& Vaz, 2011; Onishi, Cao, Ito, Shi, \& Imura, 2010; Petralli, Massetti, \& Orlandini, 2011; Steeneveld, Koopmans, Heusinkveld, vanHove, \& Holtslag, 2011), or in terms of avoided carbon emissions and energy use due to the cooler air temperature (Lin, Wu, Zhang, \& Yu, 2011); reducing air pollution, particulates and gases (Morani, Nowak, Hirabayashi, \& Calfapietra, 2011; Nowak, Crane, \& Stevens, 2006; Paoletti, Bardelli, Giovannini, \& Pecchioli, 2011; Tallis, Taylor, Sinnett, \& Freer-Smith, 2011); filtering noise and enhancing the quality of life, in terms of psychological well-being of the citizens who live close to the green areas (Chiesura, 2004; Gidlöf-Gunnarsson \& Öhrström, 2007; Hartig, Evans, Jamner, Davis, \& Garling, 2003).

The magnitude of these effects depends mainly on intrinsic factors related to urban green spaces such as: surface area, vegetation 
structure (woody, shrubs, herbaceous), species composition and location of trees in relation to the buildings (Akbari, 2002; Mirzaei \& Haghighat, 2010), and on extrinsic factors such as latitude, climate, weather and typical urban forms of the cities (Sproken-Smith \& Oke, 1998; Upmanis \& Chen, 1999).

One well-recognized effect of urban green spaces is their contribution to mitigate GHG emissions by means of atmospheric carbon dioxide $\left(\mathrm{CO}_{2}\right)$ uptake through plant photosynthesis. Several studies have quantified the $\mathrm{CO}_{2}$ sequestered and stored by urban green spaces (Escobedo, Kroeger, \& Wagner, 2011; Jo \& McPherson, 1995; McHale, McPherson, \& Burke, 2007; Nowak \& Crane, 2002; Zhao, Kong, Escobedo, \& Gao, 2010), and the long-term direct measurements of $\mathrm{CO}_{2}$ fluxes are acknowledged tools to assess the spatial and temporal variability of $\mathrm{CO}_{2}$ uptake and emission in cities (Grimmond, King, Cropley, Nowak, \& Souch, 2002).

Eddy covariance is a micrometeorological technique that measures the surface-atmosphere exchange of mass, energy and momentum, and is utilized since decades to assess the carbon exchange of natural and cultivated areas, contributing toward understanding the spatial and temporal variability of ecosystems productivity and their role in the global carbon cycle (Keenan et al., 2012). The eddy covariance technique has been also recently applied in urban and suburban areas (Crawford, Grimmond, \& Christen, 2011; Gioli et al., 2012; Helfter et al., 2011; Kordowski \& Kuttler, 2010; Pataki et al., 2009; Pawlak, Fortuniak, \& Siedlecki, 2010; Velasco \& Roth, 2010), allowing direct carbon fluxes of cities with different landscape or urban characteristics to be assessed.

In this article we compute the $\mathrm{CO}_{2}$ balance of the Municipality of Florence (emissions-uptakes) by assessing the capacity of urban green spaces of offsetting the direct anthropogenic $\mathrm{CO}_{2}$ emissions through carbon uptake. Florence was chosen as a case study, because high spatial resolution inventorial data are available and $\mathrm{CO}_{2}$ emissions of the city center are measured with eddy covariance since 2005 (Matese, Gioli, Vaccari, Zaldei, \& Miglietta, 2009). The total direct $\mathrm{CO}_{2}$ emissions of the city have been obtained, combining measured $\mathrm{CO}_{2}$ emissions with the Regional Emission Inventory (IRSE). Moreover, using different web-GIS databases we determined the surface areas of the various categories of urban green spaces in the city, and applying the IPCC methodology (IPCC, 2003 , 2006) we assigned an annual $\mathrm{CO}_{2}$ uptake factor to each urban green space category. The relative importance of absorbed vs. emitted $\mathrm{CO}_{2}$ has been assessed both temporally, by means of seasonal patterns provided by direct eddy covariance flux measurements in urban (Florence) and in a Mediterranean forest (Lecceto, Siena) environments, and spatially, by computing the $\mathrm{CO}_{2}$ balance over different areas ranging from densely urban to rural landscapes.

The paper aims to: (i) estimate the magnitude of the anthropogenic $\mathrm{CO}_{2}$ emissions of the Municipality of Florence and of the urban green spaces $\mathrm{CO}_{2}$ uptake; (ii) investigate source and sink spatial variability at high temporal resolution and their implications for urban planning.

\section{Materials and methods}

\subsection{Study area}

Florence (Lat $43^{\circ} 46^{\prime} \mathrm{N}$; Long $11^{\circ} 15^{\prime} \mathrm{E}$ ) (Fig. 1), has a typical medieval heart and the renaissance city was built on the ruins of a Roman town, in a river valley surrounded by hills. The Municipality extends over $102.3 \mathrm{~km}^{2}$, with a total surface area of urban green spaces of $75.7 \mathrm{~km}^{2}$ formed by two main categories: those in densely built-up zones, defined here as Urban Green areas (UG) extending over $29.1 \mathrm{~km}^{2}$, and Peri Urban green areas (PU), defined here as urban areas of low-density housing extending over $46.6 \mathrm{~km}^{2}$. In addition to these two main categories, there are also a total of
11,541 isolated Urban Trees (UT), many of them along avenues and streets. They include 8326 trees, managed directly by the Municipality $\left(\mathrm{UT}_{\mathrm{MF}}\right)$, and 3215 trees owned by other public institutions or by private $\left(\mathrm{UT}_{\mathrm{O}}\right)$.

The UG areas can be classified in two main categories: those managed by the Municipality of Florence $\left(U_{\mathrm{MF}}=7.7 \mathrm{~km}^{2}\right)$, for which a detailed database of morphometric parameters is available, and those represented by parks and urban green spaces managed by other public institutions and by private, defined here as other urban green space $\left(\mathrm{UG}_{\mathrm{O}}=21.4 \mathrm{~km}^{2}\right)$.

The PU areas surrounding the city are: agricultural fields on the valley floor, typically horticultural with a predominant component of herbaceous plants $\left(\mathrm{PU}_{\mathrm{H}}\right)$ and extending over a total area of $9.5 \mathrm{~km}^{2}$; agricultural fields on the hills around Florence, typically orchards, vineyards and sparse olive trees with a predominant component of woody plants ( $P U_{W}$ ), extending over an area of $33.4 \mathrm{~km}^{2}$; natural forests $\left(\mathrm{PU}_{\mathrm{F}}\right)$ extending over $3.7 \mathrm{~km}^{2}$.

According to the Florence Master Plan the total urban green spaces will be enhanced by $2.3 \mathrm{~km}^{2}$ (UGSP), and 28,450 isolated urban trees $\left(\mathrm{UT}_{\mathrm{SP}}\right)$ will be planted or replaced.

The types of urban green spaces and tree numbers have been obtained by overlapping different GIS layers of the Municipality of Florence (Open data http://datigis.comune.fi.it) (Fig. 2). In particular the web-GIS supplied layers for the $\mathrm{UG}_{\mathrm{MF}}$ and $\mathrm{UT}_{\mathrm{MF}}$ categories, that they were created in 1990 with the purpose of managing the urban green spaces. These layers are continuously updated and they provided some fundamental information for our research, such as plant species composition in each type of area, the age of the trees, and morphometric information such as diameter at breast height (DBH). The other urban green space categories were determined by overlapping the GIS layers provided by the Florence Master Plan that take all the other categories into account; unfortunately these GIS layers did not provide detailed information about plant species. All the maps created with this overlapping were subsequently validated through digital orthophotos.

\subsection{The IRSE data}

The IRSE emission database is based on the Corinair methodology (EEA, 2007) and was developed by the Regional Administration of Tuscany (IRSE, 2010). It contains yearly amounts of pollutants emitted since 1995 , spatially disaggregated at $1 \mathrm{~km}^{2}$ resolution, on the basis of spatial proxies of emission intensity. Emission sources are classified according to the European standard nomenclature ' 97 called SNAP (Selected Nomenclature for Air Pollution), and include three categories: (i) diffuse: that are not localized, but distributed on the territory; (ii) punctual: that are geographically localized; (iii) linear: related to linear infrastructure such as roads and railway lines. In our study, by overlapping the administrative borders of the Municipality of Florence with the IRSE spatialized data, we determined the annual direct $\mathrm{CO}_{2}$ emissions (Fig. 3). In practice we considered only the $\mathrm{CO}_{2}$ emissions within the city boundaries (Scope 1, defined by Kennedy et al., 2010) and recently adopted in the Global Protocol for Community-Scale Greenhouse Gas Emissions (C40 \& ICLEI, 2012C40, ICLEI, World Resources Institute, 2012).

\subsection{Urban and forest $\mathrm{CO}_{2}$ flux measurements}

Two eddy covariance sites have been used in this study to measure $\mathrm{CO}_{2}$ fluxes. The first was installed in September 2005 at the Ximeniano Observatory (Lat $43^{\circ} 47^{\prime} \mathrm{N}$; Long $11^{\circ} 15^{\prime} \mathrm{E}$ ) (Fig. 1), in the city center where fluxes are entirely governed by anthropogenic emissions, considering the lack of green space in the flux footprint (Matese et al., 2009). Observed $\mathrm{CO}_{2}$ fluxes are therefore always a net source throughout the year, of $309( \pm 42) \mathrm{tCO}_{2} \mathrm{ha}^{-1} \mathrm{y}^{-1}$ 


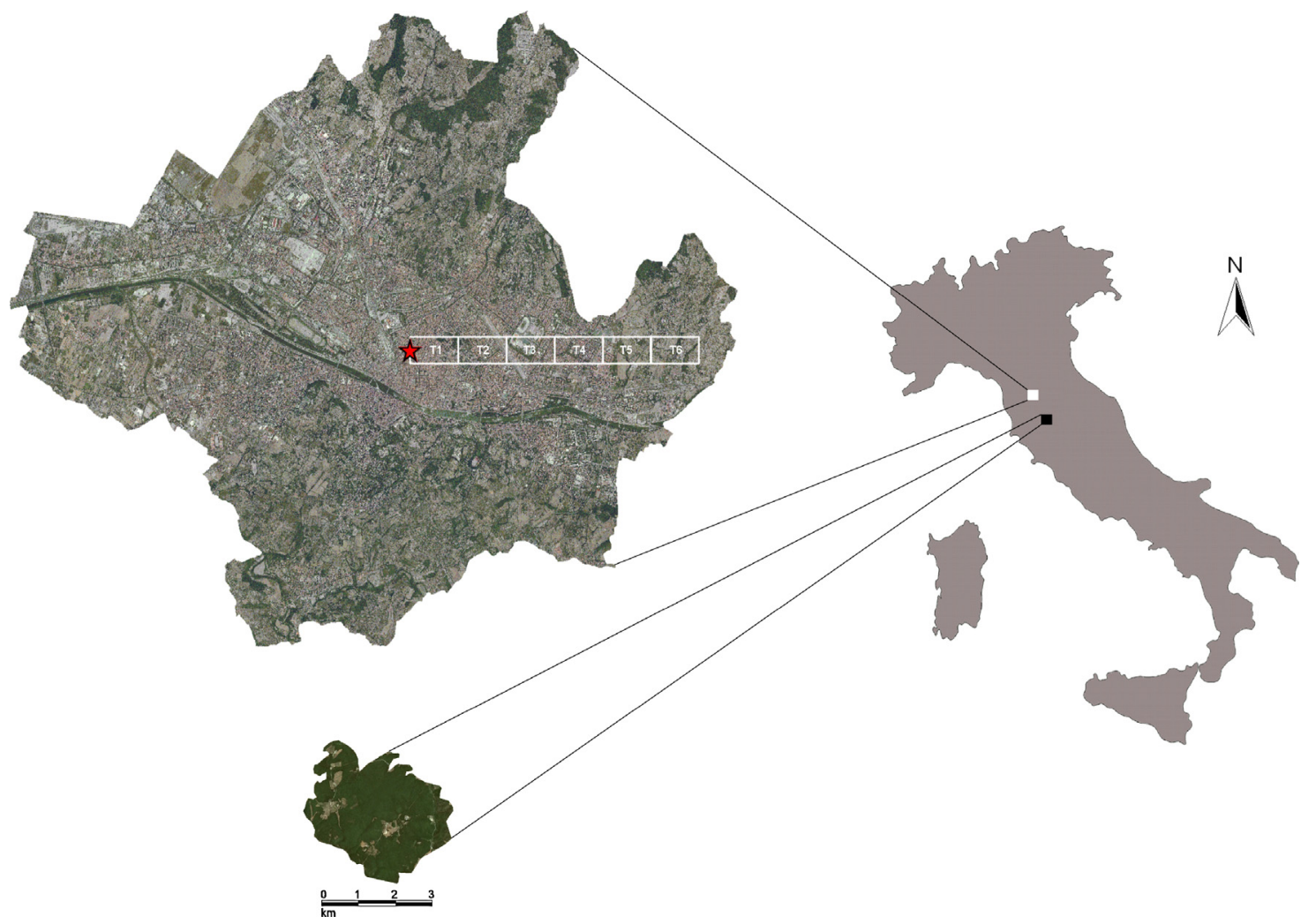

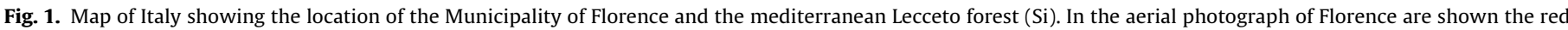
star to indicate the Ximeniano Observatory site, and the urban transect, divided in six sections from T1 to T6 to represent a continuum from urban to rural.

(Gioli et al., 2012). The second was installed in June 2005 in the Lecceto Mediterranean forest (Lat $43^{\circ} 18^{\prime} \mathrm{N}$; Long $11^{\circ} 16^{\prime} \mathrm{E}$ ) (Fig. 1), a holm oak coppice of 20 years age, located $70 \mathrm{~km}$ south of Florence and extending over an area of about $9 \mathrm{~km}^{2}$. Mean canopy height is $8.6 \mathrm{~m}$ with a mean tree DBH of $9.0 \mathrm{~cm}$ and density of 2948 trees ha $^{-1}$, while mean annual Net Ecosystem Exchange (NEE) is -13.2 $( \pm 3.7) \mathrm{tCO}_{2} \mathrm{ha}^{-1} \mathrm{y}^{-1}$ (Magno, Gioli, Vaccari, \& Canfora, 2010), representing a $\mathrm{CO}_{2}$ sink from the atmosphere. Both towers, which are still operating, use the acquisition procedure indicated by Matese et al. (2008) and adopt the same flux data processing methodology (Baldocchi, 2003).

\subsection{Urban green spaces and urban trees $\mathrm{CO}_{2}$ uptake}

Using the detailed information about surface areas, type of green space, species composition and morphometric measurements of the single trees, provided by the Municipality, we assigned an annual $\mathrm{CO}_{2}$ uptake factor for $\mathrm{UG}_{\mathrm{MF}}$ and $\mathrm{UT}_{\mathrm{MF}}$ categories, through an analysis of the literature and using the Guidelines of the IPCC (IPCC, 2003, 2006), which provide a tiered structure of methods with varying degrees of complexity. These $\mathrm{CO}_{2}$ uptake factors were then applied to other urban green space categories: $\mathrm{UG}_{\mathrm{O}}, \mathrm{UT}_{\mathrm{O}}, \mathrm{UG}_{\mathrm{SP}}$ and $\mathrm{UT}_{\mathrm{SP}}$

The $U_{\mathrm{MF}}$ is formed by four categories: Lawn, Forest, Mixed Vegetation and Lawn with Shrubs, and for each category we assigned a $\mathrm{CO}_{2}$ uptake factor (Table 1 ). For Lawn category we adopted the value of $4.3 \mathrm{tCO}_{2} \mathrm{ha}^{-1} \mathrm{y}^{-1}$, corresponding to the value for the annual Net Primary Production of Grassland of the Warm Temperate-Dry Climate Zone (Chapter 3.4 - IPCC, 2003). For Forest category we adopted the value of $5.8 \mathrm{tCO}_{2} \mathrm{ha}^{-1} \mathrm{y}^{-1}$ determined in a specific case study using the Cascine Park in Florence (Paoletti et al., 2011). For Mixed Vegetation, defined as an area with trees and shrubs, and Lawn with Shrubs categories, we added a value of
$0.07 \mathrm{tCO}_{2} \mathrm{ha}^{-1} \mathrm{y}^{-1}$ as the contribution of the shrubs, according to Zirkle, Lal, Augustin, and Follett (2012, chapter 14, part 3), to the previous uptake factor identified for Lawn and Forest.

Since 2002, in the Municipality of Florence database, each tree has been identified and classified in terms of botanical species, geographical position and morphometric measurements.

To determine the $\mathrm{CO}_{2}$ uptake factor for the tree category we applied the following equation, (IPCC, 2003):

$\Delta \mathrm{CO}_{2}=\frac{\left(\mathrm{CO}_{2(t 2)}-\mathrm{CO}_{2(t 1)}\right)}{\left(t_{2}-t_{1}\right)}$

where $\Delta \mathrm{CO}_{2}=$ carbon dioxide content difference. $\mathrm{CO}_{2(t 2)}=$ carbon dioxide content referred to time 2. $\mathrm{CO}_{2(t 1)}=$ carbon dioxide content referred to time 1. $t_{2}=$ time $(2011) t_{1}=$ time (2006).

To determine the $\mathrm{CO}_{2}$ content of the urban trees, as required for in Eq. (1), we used the Stock Change Method (IPCC, 2003) applying the following equation for each plant genus:

$C_{\text {tot }}=(V \times D \times \mathrm{BEF}) \times(1+R) \times C F$

where $C_{\text {tot }}=$ total carbon (above + below biomass). $V=$ tree volume, $\mathrm{m}^{3} . D=$ wood density, $t \mathrm{~m}^{-3}$. BEF = Biomass Expansion Factor. $R=$ Root-to-Shoot Ratio. $C F=$ carbon fraction of the dry biomass.

The tree volume $(V)$ was determined considering the DBH values for each plant genus, using dendrometric tables at single entry (CRA, 1980). The wood densities $(D)$, for each plant genus, were obtained using the values indicated for Italy by FAO (2005); we used the values of 1.3 for conifer species and 1.4 for broadleaf species as BEF (IPCC, 2003), while for the CF we used the standard value of 0.5 (IPCC, 2003).

The average $\mathrm{CO}_{2}$ uptake factor per tree, determined following the above procedure (Table 2), was then used to evaluate the total annual $\mathrm{CO}_{2}$ uptake of the urban trees in Florence. 

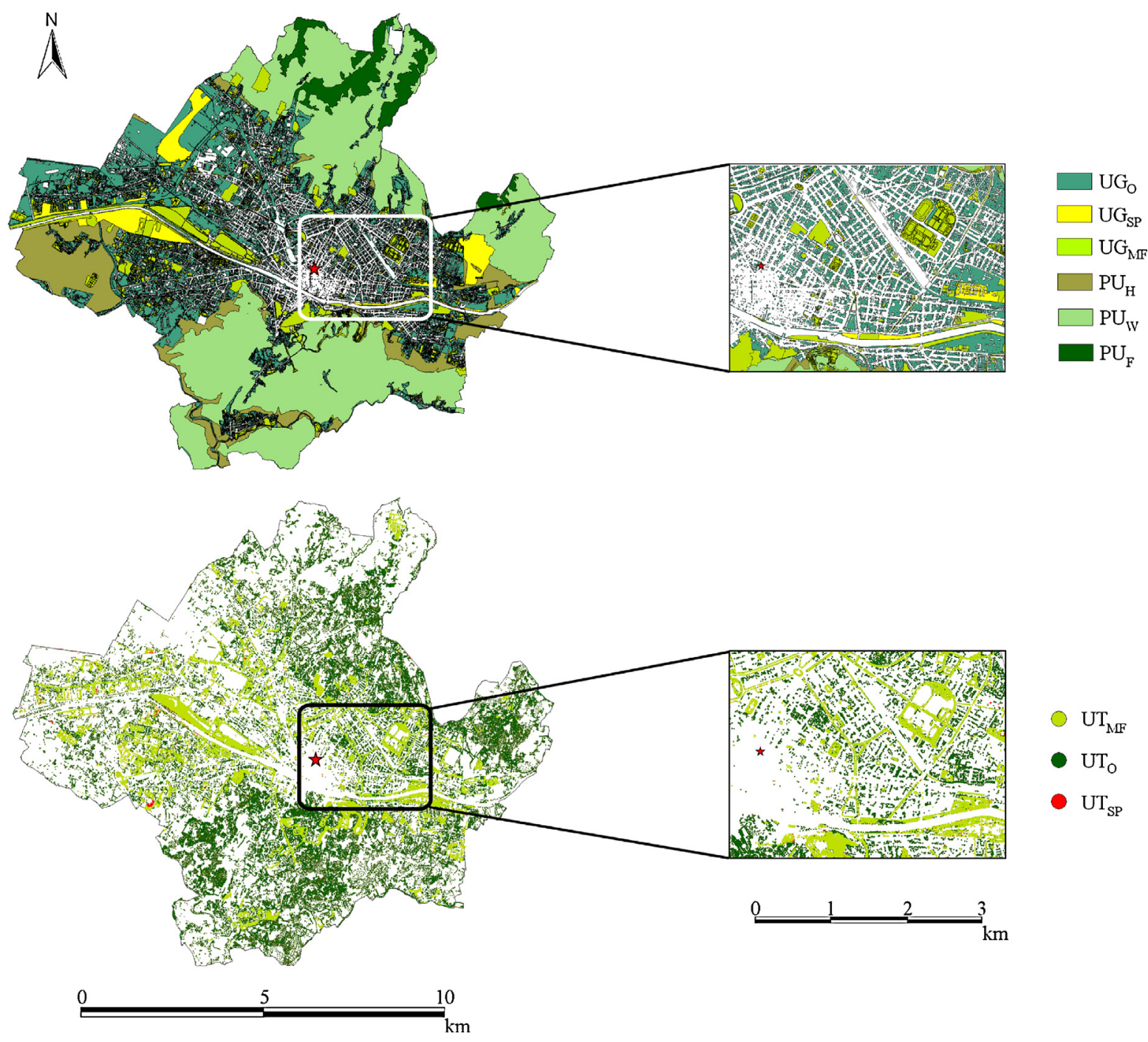

Fig. 2. Urban green spaces (upper map) and urban trees (lower map) of the Municipality of Florence.

Table 1

Categories of the $\mathrm{UG}_{\mathrm{MF}}$, with indications about the total surface (ha), the $\mathrm{CO}_{2}$ uptake factor $\left(\mathrm{tCO}_{2} \mathrm{ha}^{-1} \mathrm{y}^{-1}\right)$ and the total $\mathrm{CO}_{2}$ uptake per year $\left(\mathrm{tCO} \mathrm{y}^{-1}\right)$.

\begin{tabular}{lcclr}
\hline Categories & Surface (ha) & $(\%)$ & $\mathrm{CO}_{2}$ uptake factor $\left(\mathrm{tCO}_{2} \mathrm{ha}^{-1} \mathrm{y}^{-1}\right)$ & Total $\mathrm{CO}_{2}$ uptake $\left(\mathrm{tCO}_{2} \mathrm{y}^{-1}\right)$ \\
\hline Lawn & 562.3 & 73.0 & 4.3 & 2417.9 \\
Forest & 84.79 & 11.0 & 5.8 & 491.8 \\
Mixed vegetation & 79.75 & 10.4 & 5.9 & 470.5 \\
Lawn with shrub & 43.16 & 5.6 & 4.4 & 189.9 \\
& 770 & 100 & & 3570.1 \\
\hline
\end{tabular}

Table 2

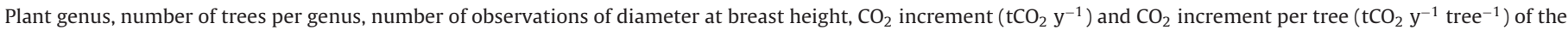
10 genera of the trees managed by the Municipality of Florence and used to determine the $\mathrm{CO}_{2}$ uptake factor per tree.

\begin{tabular}{|c|c|c|c|c|c|c|}
\hline & Plant Genus & Common name & No. trees & No. obs. & $\mathrm{CO}_{2}$ Incr. $\left(\mathrm{tCO}_{2} \mathrm{y}^{-1}\right)$ & $\mathrm{CO}_{2}$ Incr. per tree $\left(\mathrm{tCO}_{2} \mathrm{y}^{-1}\right.$ tree $\left.^{-1}\right)$ \\
\hline 1 & Tilia spp. L. & Linden tree & 8621 & 10,559 & 357.8 & 0.0415 \\
\hline 2 & Quercus spp. L. & Oak tree & 8097 & 9048 & 105.8 & 0.0131 \\
\hline 3 & Cupressus spp. L. & Cypress tree & 8034 & 8683 & 244.6 & 0.0304 \\
\hline 4 & Celtis spp. L. & European nettle tree & 6765 & 8178 & 166.4 & 0.0246 \\
\hline 5 & Pinus spp. L. & Pine tree & 5219 & 6748 & 344.7 & 0.0660 \\
\hline 6 & Platanus spp. L. & Plane tree & 4415 & 6580 & 124.2 & 0.0281 \\
\hline 7 & Acer spp. L. & Maple tree & 3626 & 2119 & 28.8 & 0.0079 \\
\hline 8 & Olea spp. L. & Olive tree & 3539 & 2907 & 12.1 & 0.0034 \\
\hline 9 & Ulmus spp. L. & Elm tree & 2148 & 3303 & 76.6 & 0.0357 \\
\hline \multirow[t]{2}{*}{10} & Fraxinus spp. L. & Ash tree & 2087 & 1213 & 16.6 & 0.0079 \\
\hline & & & 52,551 & & 1477.6 & 0.026 (avg.) \pm 0.01 \\
\hline
\end{tabular}




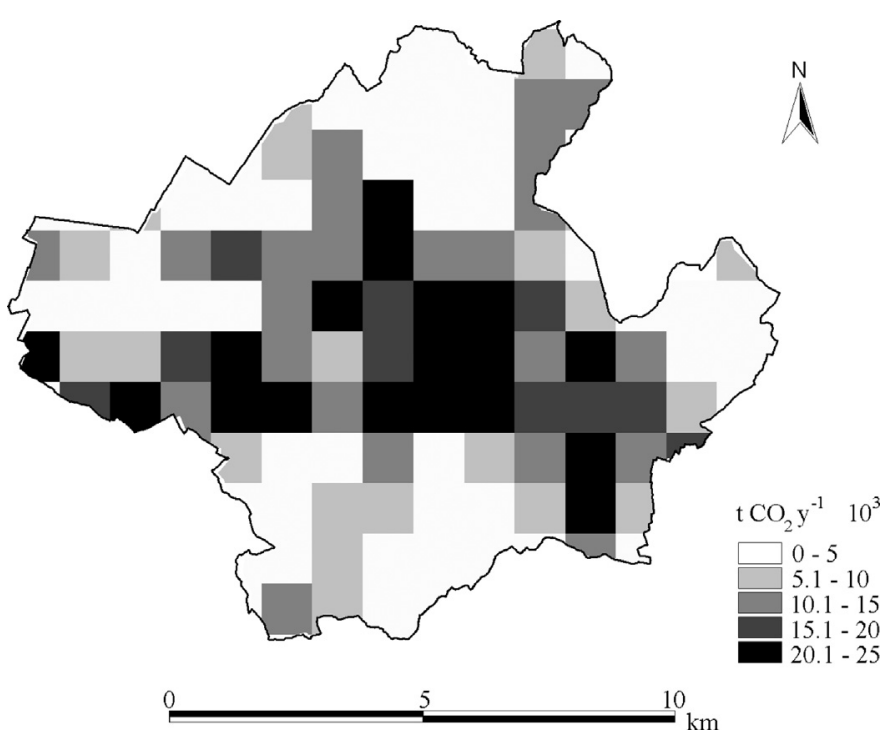

Fig. 3. Direct carbon dioxide emissions of the Municipality of Florence expressed as $\mathrm{ktCO}_{2} \mathrm{y}^{-1}$.

The $\mathrm{CO}_{2}$ uptake factor of $5.0 \mathrm{tCO}_{2} \mathrm{ha}^{-1} \mathrm{y}^{-1}$ was chosen for $\mathrm{PU}_{\mathrm{H}}$ according to the results of Ceschia et al. (2010), who evaluated, through the eddy covariance technique, the greenhouse gas budgets of 15 crop sites across Europe, covering a large climatic gradient and a wide range of agricultural management practices. For the $\mathrm{PU}_{\mathrm{W}}$ we applied a $\mathrm{CO}_{2}$ uptake factor of $14.7 \mathrm{tCO}_{2} \mathrm{ha}^{-1} \mathrm{y}^{-1}$ according to Sofo et al. (2005), who evaluated the dry matter accumulation and partitioning in the different plant organs of Mediterranean orchards, and for the $\mathrm{PU}_{\mathrm{F}}$, we applied the $\mathrm{CO}_{2}$ uptake factor of $13.2 \mathrm{tCO}_{2} \mathrm{ha}^{-1} \mathrm{y}^{-1}$ measured by the eddy covariance tower installed on the Lecceto Mediterranean forest.

\subsection{Urban transect}

An urban transect of $6 \mathrm{~km}$ in length was defined from Florence city center to the eastern peri-urban area, formed by 6 sections of $1 \mathrm{~km}$ in length and $0.5 \mathrm{~km}$ width, to assess the spatial variability of some landscape metrics indices and compare with $\mathrm{CO}_{2}$ emissions (Fig. 1). The direction of the transect was chosen because it is representative of the average distribution of the land cover classes found in the Municipality (data not shown). The first section (T1) was set in the city center close to the Ximeniano Observatory and the last section (T6) in the peri-urban area. For each section, 3 landscape metric indices have been determined, classifying the land use in 8 classes: urbanized (built-up, residential); urban infrastructure (streets, communication/utilities, railway stations, cemeteries) and the previously defined types of urban green spaces $\left(U_{\mathrm{MF}}, \mathrm{UG}_{\mathrm{O}}\right.$, $\left.\mathrm{UG}_{\mathrm{SP}}, \mathrm{UT}_{\mathrm{MF}}, \mathrm{UT}_{\mathrm{O}}, \mathrm{UT}_{\mathrm{SP}}\right)$. The indices, determined in each section of the transect, are: the Pland index (Pland), indicating the area percentage of each land use type with respect to total area; the Shannon's evenness index (SHEI), indicating the degree of evenness among patch types; the patch relative density (PRD), indicating the number of patches in each section.

\section{Results}

\section{1. $\mathrm{CO}_{2}$ uptake}

The total urban green spaces of the Municipality of Florence uptake $72.5( \pm 18.2) \mathrm{ktCO}_{2} \mathrm{y}^{-1}$; of these, $13.5 \mathrm{ktCO}_{2} \mathrm{y}^{-1}$ are taken up by the UG $\left(\mathrm{UG}_{\mathrm{MF}}+\mathrm{UG}_{\mathrm{O}}\right), 58.7 \mathrm{ktCO}_{2} \mathrm{y}^{-1}$ by the PU $\left(\mathrm{PU}_{\mathrm{H}}+\mathrm{PU}_{\mathrm{W}}+\mathrm{PU}_{\mathrm{F}}\right)$; and $0.3 \mathrm{ktCO}_{2} \mathrm{y}^{-1}$ by the UT $\left(\mathrm{UT}_{\mathrm{MF}}+\mathrm{UT}_{\mathrm{O}}\right)$.
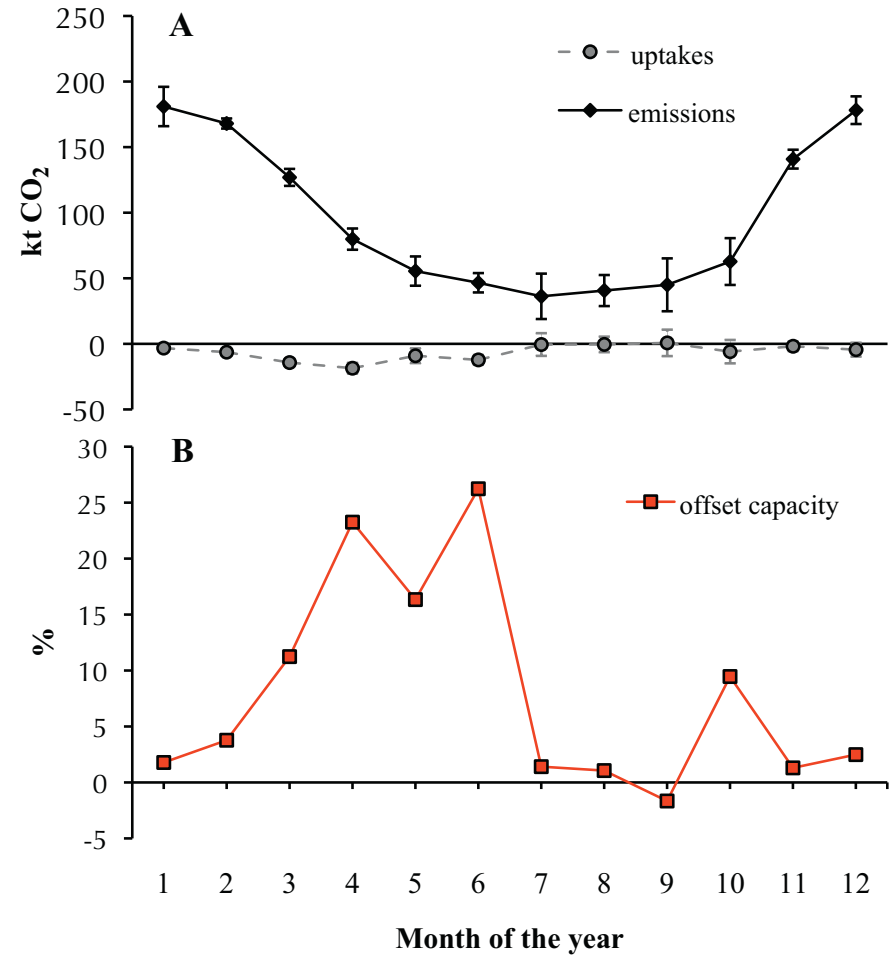

Fig. 4. (A) Monthly $\mathrm{CO}_{2}$ anthropogenic emissions (black line) and urban green spaces uptakes (gray line) errors bars represent 95\% confidence intervals of the averages; (B) Monthly offsett capacity (absolute percentage value) of the urban green spaces with respect to $\mathrm{CO}_{2}$ emissions.

Almost $80 \%$ of the total $\mathrm{CO}_{2}$ uptake by the urban green spaces is due to the PU areas, with a predominant contribution from the orchards, olive trees and grapevines on the hills around the city. For temporal disaggregation of the $\mathrm{CO}_{2}$ uptake we used the $\mathrm{CO}_{2}$ flux measurements measured at the Lecceto site (Fig. 4). On a seasonal basis, the Lecceto forest is a higher carbon sink during spring and early summer, while it becomes a net, small carbon source during mid-summer. This seasonal pattern is known to be typical of most Mediterranean ecosystems that are water limited during the summer and on average about $83 \%$ of the annual carbon uptake of the Lecceto forest occurs from January to June.

\section{2. $\mathrm{CO}_{2}$ emissions}

Florence's direct $\mathrm{CO}_{2}$ emissions have been computed by means of two information sources: the IRSE inventorial yearly emission database spatially disaggregated at $1 \mathrm{~km}^{2}$ resolution and the eddy flux site located in the city center. Eddy covariance data have been used in two ways: (i) to directly validate IRSE inventorial data at the location of the tower; (ii) to provide a temporal emission pattern at monthly scale, which can be applied to yearly inventorial data to obtain a monthly emission trend. We found a relatively good agreement between the $\mathrm{CO}_{2}$ emissions measured at the urban flux tower $\left(309 \pm 42 \mathrm{tCO}_{2} \mathrm{ha}^{-1} \mathrm{y}^{-1}\right)$, and the corresponding pixel extracted by the IRSE $\left(255 \mathrm{tCO}_{2} \mathrm{ha}^{-1} \mathrm{y}^{-1}\right)$, that justifies using IRSE data on the entire Municipality of Florence, revealing a total direct anthropogenic $\mathrm{CO}_{2}$ emission of $1161.5( \pm 136) \mathrm{ktCO}_{2} \mathrm{y}^{-1}$. The seasonal pattern of direct $\mathrm{CO}_{2}$ emissions measured at the Ximeniano Observatory was used for temporal disaggregation of the inventorial estimates, demonstrating that the monthly direct emissions of the city are highest during the winter (December and January) and lowest during summer (July and August), according to domestic heating usage (Fig. 4). 


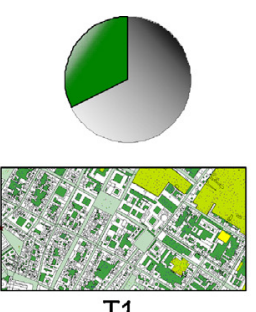

T1
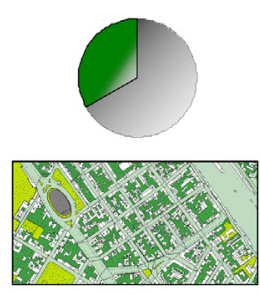

T2
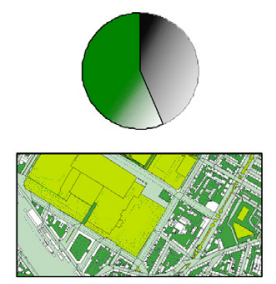

T3
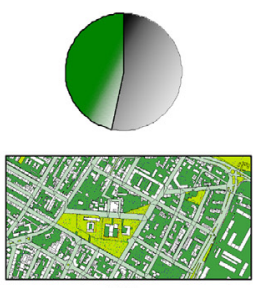

T4
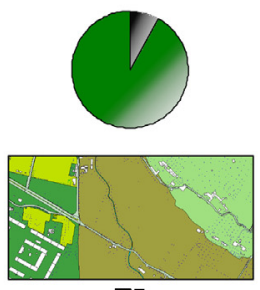

T5
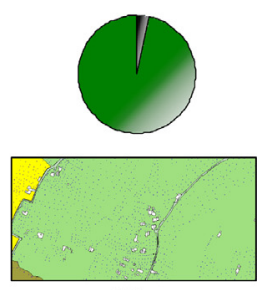

T6

URBAN

RURAL

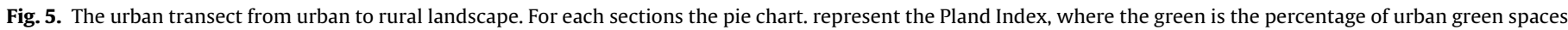
and the gray is the percentage of the urbanized areas. Pland index was referred to the section surface equal to $0.5 \mathrm{~km}^{2}$.

\section{3. $\mathrm{CO}_{2}$ balance}

Within a carbon balance perspective, the total sink of urban green spaces of the Municipality of Florence offset $6.2 \%$ of the total direct anthropogenic $\mathrm{CO}_{2}$ emissions. Of this, $1.1 \%$ is made by the UG and $5.1 \%$ by the PU. When including the Florence Master Plan scenario in the balance computation, the offset capacity of urban green spaces grows to $6.4 \%$. The time disaggregation on a monthly scale (Fig. 4), reveals that the urban green spaces are more efficient in offsetting the direct anthropogenic $\mathrm{CO}_{2}$ emissions during March (11.2\%), April (23.3\%), May (16.3\%) and June (26.2\%), as these are the most productive months associated to relatively low anthropogenic emissions.

\subsection{Urban transect}

The Pland index reveals a clear pattern of the level of urbanization of the city: T1 and T2 have the higher percentage of urbanized area, on average more than 50\%; T3 and T4 have approximately the same percentage of urbanized and urban green spaces; while in T5 and T6, the percentage of urbanized area is less than 10\% (Fig. 5).

SHEI index has almost the same value along the urban transect, and considering that it ranges from 0 (completely uneven landscape distribution) to 1 (completely even), every patch class abundance is of the same magnitude (Fig. 6A). The section of the urban transect that shows the lowest value of the SHEI index is T1, while the one with the highest value is $\mathrm{T} 5$.

The patch relative density (PRD), which is an indicator of landscape fragmentation, exhibits.

A positive correlation $(r=0.89)$ with total $\mathrm{CO}_{2}$ emissions (Fig. 6B), and negative correlation $(r=-0.85)$ with $\mathrm{CO}_{2}$ uptake (Fig. 6C). PRD values are higher in correspondance to the sectors closer to the city center (T1 and T2), while they are not significantly affected by the forecast interventions planned in the Florence Master Plan (Fig. 6C).

\section{Discussions}

The total annual $\mathrm{CO}_{2}$ uptake by the urban green spaces of the entire Municipality of Florence offsets $6.2 \%$ of the total direct anthropogenic $\mathrm{CO}_{2}$ emissions. This is quite high, with respect to other urban areas. Escobedo, Varela, Zhao, Wagner, and Zipperer (2010), used field modeled and spatial data on urban trees to analyze the $\mathrm{CO}_{2}$ sequestered by trees compared to the total emissions of two subtropical American cities, Gainesville and Miami-Dade, with the result that the urban trees offset only $3.4 \%$ and $1.8 \%$. The higher value of Florence is due to a combination of two factors: (i) we consider only the direct emissions to the atmosphere instead of total; (ii) the distribution of the urban green spaces, the majority of which are located in the PU area. In fact, if we compute the offsetting capacity not considering the PU contribution we obtain a value of $1.1 \%$. These results point out that particular attention must be taken in urban planning to preserve $\mathrm{PU} \mathrm{CO}_{2}$ offsetting capacity, also because newly built areas will occupy PU surfaces, as indicated by the Florence Master Plan. This follows an urbanization model found also in Rome (Salvati, Munafo, Gargiulo Morelli, \& Sabbi, 2012), which has evolved in the last decades, from a "compact growth model" to a "disperse model" (Schneider \& Woodcock, 2008).

The application of the IPCC methodology to estimate the magnitude of $\mathrm{CO}_{2}$ uptake enables the role of urban green spaces in the urban carbon balance to be quantified. The mean annual $\mathrm{CO}_{2}$ uptake for urban lawns used in this study is comparable in magnitude to that indicated by Conant, Paustian, and Elliott (2001) and Qian and Follett (2002), who estimated that lawns have a potential $\mathrm{CO}_{2}$ uptake rate of $3.6 \mathrm{tCO}_{2} \mathrm{ha}^{-1} \mathrm{y}^{-1}$ and it is also comparable to the uptake factors published by Jo and McPherson (1995).

The mean $\mathrm{CO}_{2}$ uptake factor per tree applied in this study $\left(26 \mathrm{kgCO}_{2}\right.$ tree $\left.^{-1} \mathrm{y}^{-1}\right)$ is comparable with the findings of Nowak and Crane (2002), who reported a $\mathrm{CO}_{2}$ uptake factor ranging from 12.2 to $21.2 \mathrm{kgCO}_{2}$ tree $\mathrm{y}^{-1}$. Moreover in a recent study done on the Cascine Park, the largest green area in Florence that covers 118 ha, using the UFORE model, a mean annual uptake factor has been determined of $33.8 \mathrm{kgCO}_{2}$ tree $\mathrm{y}^{-1}$ (Paoletti et al., 2011). The DBH data used in our study, provided by the Municipality of Florence, allowed to us to rule out the effect of the inter-annual variability of tree growth. In fact, even if the exact dates of the DBH data samplings are not known, our calculations are based on a large number of samples taken during each year from 2006 to 2011, with more than 9800 DBH measurements per year on average.

The temporal disaggregation of the emissions and uptakes of the city (Fig. 4) represents a new level of information that may be used to estimate the efficacy of interventions and policies aimed at reducing $\mathrm{CO}_{2}$ emissions and enhancing $\mathrm{CO}_{2}$ uptakes. The maximum efficiency of urban green spaces to offset emissions is during spring and it is very low during winter and summer months. The inefficacy of the green spaces during these two seasons is related: for the winter months, to high $\mathrm{CO}_{2}$ emissions due to the domestic heating and the lower air temperature that limits plant carbon uptake, and for the summer period, to lack of water and high air temperatures that inhibit carbon uptake, even though the $\mathrm{CO}_{2}$ emissions during summer are lower than in other seasons of the year. Within this perspective, policies aimed at decreasing $\mathrm{CO}_{2}$ emissions in winter months will be more efficient than those aimed at increasing $\mathrm{CO}_{2}$ uptake, which still remain controlled by environmental factors such as air temperature and precipitation.

We extracted a sub-set of our $\mathrm{CO}_{2}$ balance results on an urban transect taking into account a recent application of the transect theory developed by urban designers named "Smart Code" (www.smartcodecentral.org). This has recently been adopted as the cornerstone of a renewed sustainable design variously addressed over the past decades in the following seminal texts: The Smart 

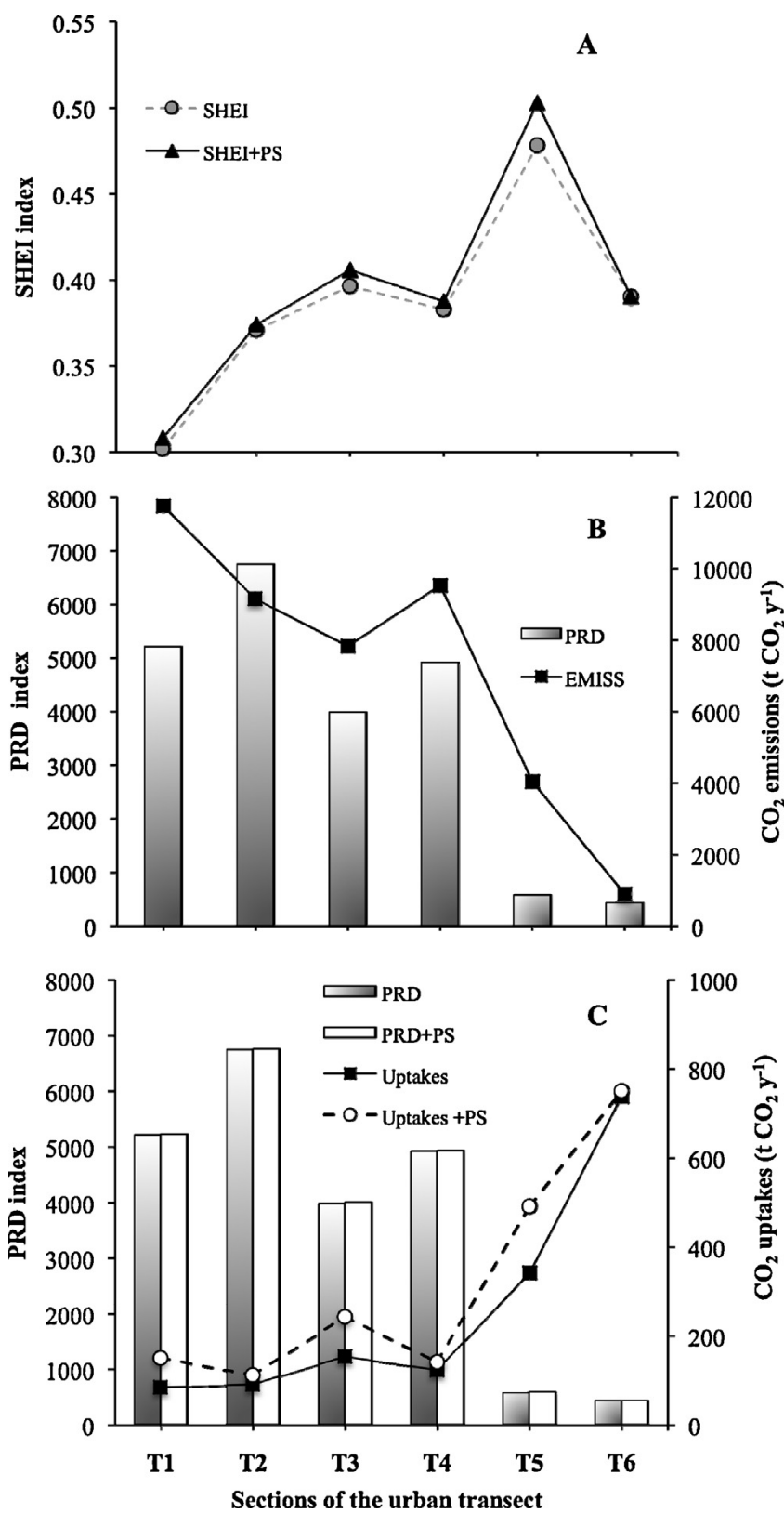

Fig. 6. (A) Shannon's evenness index (SHEI) calculated for each sections of the urban transect considering the actual patches distribution (SHEI, grays symbols) and the patches distribution if all the interventions forecast by Master Plan will be done (SHEI + PS, black symbols). (B) Actual patch richness index (PRD) gray bars, and the total $\mathrm{CO}_{2}$ emissions ( $\mathrm{tCO}_{2} \mathrm{y}^{-1}$ ) black symbols, for each sections of the urban transect. (C) Actual PRD index gray bars, and future PRD index (PRD + PS, white bars) with the new patches of the Master Plan and the actual $\mathrm{CO}_{2}$ uptake $\left(\mathrm{tCO}_{2} \mathrm{y}^{-1}\right)($ Uptakes, black symbols), and the future $\mathrm{CO}_{2}$ uptake $\left(\mathrm{tCO}_{2} \mathrm{y}^{-1}\right)$ (Uptakes + PS, gray symbols and dotted line)

Growth Manual (Duany, Speck, \& Lydon, 2009), Landscape Urbanism (Waldheim, 2006), New Urbanism (Katz, 1994); Ecological Urbanism (Mostafavi \& Doherty, 2010) and Sustainable Urbanism (Farr, 2007). The analysis of Florence's urban transect represents an attempt to merge a landscape analysis with a quantitative carbon balance analysis. SHEI index along the different sections indicates that the city center is unbalanced compared to the T5, which exhibits the best performances with highest SHEI index. The Florence Master Plan will enhance the SHEI index in most of the sections, contributing to balance the distribution of class patches in the urban transect (Fig. 6A). The fragmentation of patches in the various sections shows a good agreement with the total $\mathrm{CO}_{2}$ emissions
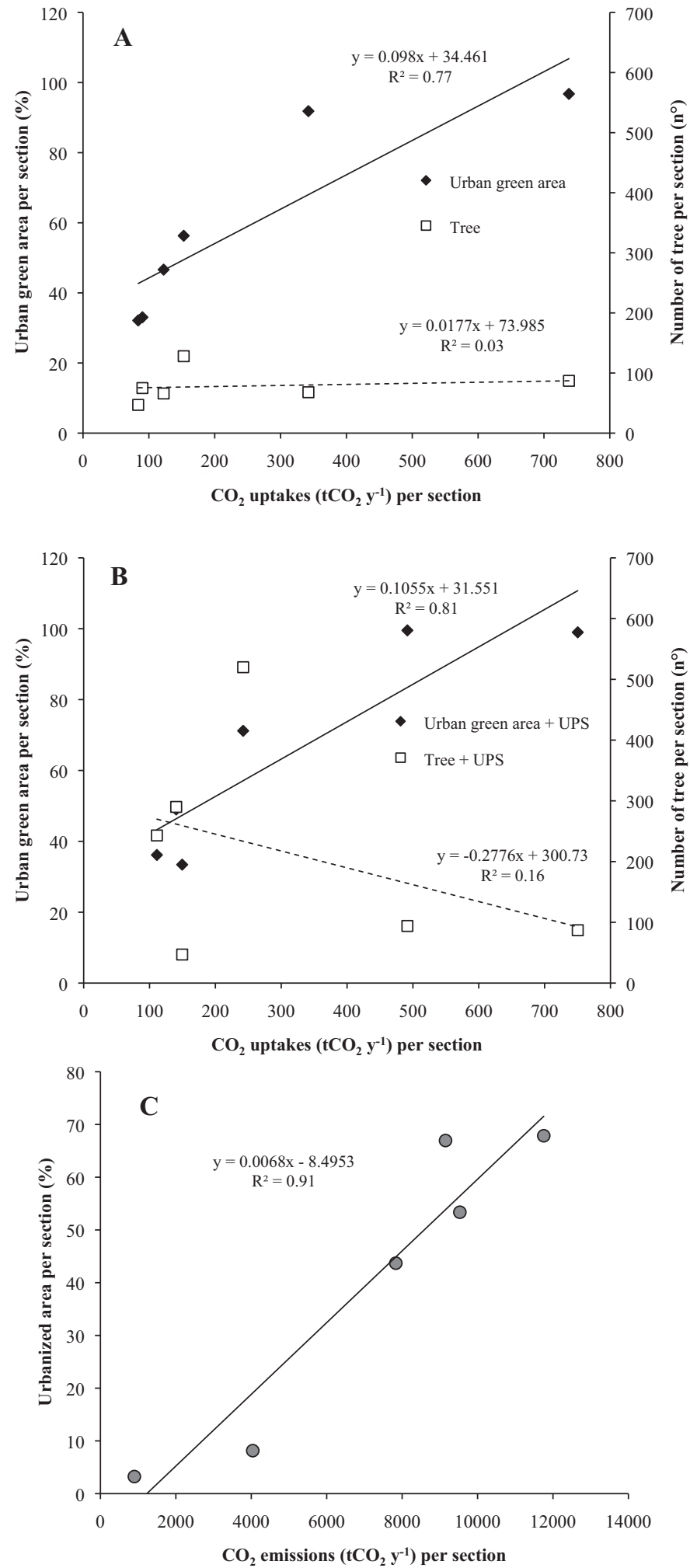

Fig. 7. Direct carbon dioxide emissions and uptake per section of the urban transect. (A) Actual urban green spaces (black symbols and line), vs actual $\mathrm{CO}_{2}$ uptakes ( $\mathrm{tCO}_{2}$ $\mathrm{y}^{-1}$ ) on left axis and actual total number of urban trees (open symbols, dotted line); (B) Forecast urban green spaces as sum of the actual and forecast area of the Master Plan (black symbols and line), vs forecast $\mathrm{CO}_{2}$ uptake $\left(\mathrm{tCO}_{2} \mathrm{y}^{-1}\right)$ on left axis and forecast total number of urban trees as sum of $\mathrm{UT}_{\mathrm{MF}}, \mathrm{UT}_{\mathrm{O}}$ and $\mathrm{UT}_{\mathrm{PS}}$ (open symbols, dotted line); C) Urbanized area per section (gray symbols and black line) vs the direct carbon dioxide emissions $\left(\mathrm{tCO}_{2} \mathrm{y}^{-1}\right)$. 
(Fig. 6B), confirming that this fragmentation is related to the $\mathrm{CO}_{2}$ emissions, probably through the percentage of built-up areas. The relations reported in Fig. 7A-C between $\mathrm{CO}_{2}$ uptake/emission and green/urbanized areas represent an innovative approach to merge a landscape analysis with a quantitative environmental analysis, capable of evaluating the efficacy of the Florence Master Plan, and that could be applied in other urban areas of the city.

The relations between the sum of the percentage of continuous green areas (sum of the categories $\mathrm{UG}_{\mathrm{MF}}, \mathrm{UG}_{\mathrm{O}}, \mathrm{PU}_{\mathrm{H}}, \mathrm{PU}_{\mathrm{W}}$ and $\mathrm{PU}_{\mathrm{F}}$ ) and the total $\mathrm{CO}_{2}$ uptake by each section of the urban transect for both the existing (Fig. 7A; $R^{2}=0.77$ ) and future green area, according to the Florence Master Plan (Fig. $7 \mathrm{~B} ; R^{2}=0.81$ ), clearly demonstrate that the main driver for the $\mathrm{CO}_{2}$ uptake in each sector is represented by the continuous green areas instead of the total number of trees (Fig. 7A; $R^{2}=0.03$ and Fig. 7B; $R^{2}=0.16$ ). Moreover, the correlation between the total urbanized area, defined here as the sum of the patches classified as urbanized (built-up, residential), urban infrastructure (streets, railway stations and cemeteries) and the total $\mathrm{CO}_{2}$ emissions $\left(\mathrm{tCO}_{2} \mathrm{y}^{-1}\right.$ ) for each section (Fig. $7 \mathrm{C}$; $R^{2}=0.91$ ), demonstrates that the percentage of urbanized area in each sector is the main driver for the $\mathrm{CO}_{2}$ emissions.

\section{Conclusions}

There is a general need to increase knowledge about the role of urban green spaces in offsetting GHG emissions, in particular with the direct measurements of carbon uptake and emission in urban environments, as recently pointed out by Pataki et al. (2011). The approach applied in this study is a combination of eddy covariance observations in urban and natural environments, inventorial emission data and carbon stock assessment methods provided by IPCC $(2003,2006)$ that might easily be applied in other cities. The total $\mathrm{CO}_{2}$ emissions offsetting capacity of the urban green spaces of the Municipality of Florence, excluding the contribution of the PU areas, is very low (1.1\%). Within a carbon balance perspective, instead of incrementing the efficacy of urban green spaces to balance $\mathrm{CO}_{2}$ emissions, the implementation of measures for reducing the $\mathrm{CO}_{2}$ emissions could provide better results. Moreover our calculations only concern the direct $\mathrm{CO}_{2}$ emissions, and if considering also indirect emissions in a full carbon balance perspective the offsetting capacity would be even lower. To offset the total direct $\mathrm{CO}_{2}$ emissions of the city more than $880 \mathrm{~km}^{2}$ of natural forest would be necessary with the same ecophysiological characteristics as the Lecceto Mediterranean forest, corresponding to approximately 8 times the entire surface area of the Municipality. This fact might encourage re-thinking the role of urban green spaces, that have a lot of beneficial effects, such as reducing the urban heat island, reducing air pollution, particulates and gases, filtering noise and enhancing the well-being of the citizens who live close to the green areas. Quantification of the $\mathrm{CO}_{2}$ uptake by urban green spaces might be useful to the urban planner for managing the "free city space" concept (Odum, 1971), defined as space in the urban territory covered by green. The arguments of this work might offer scientific support to those urban policies aimed at limiting the demand for land, on the one hand, and containing the densification of suburbs, on the other. The urban green spaces have several different roles, including the offsetting capacity of anthropogenic $\mathrm{CO}_{2}$ emissions analyzed in this study, that should be carefully considered by urban planners and designers to effectively contribute to the development of a sustainable urban design.

\section{Acknowledgements}

The authors would like to acknowledge the contributions of: Alessandro Matese, Francesco Sabatini and Alessandro Zaldei
(IBIMET-CNR), for their valuable technical assistance in the management of the eddy covariance flux towers. Ramona Magno (Consorzio LaMMA) is acknowledged for providing the IRSE Inventory data. A special thanks to: Emilio Borchi and Renzo Macii of the Fondazione Osservatorio Ximeniano (Fi); Emanuela Lupi and Marisa Sabbia of the Municipality of Florence; the Laboratory on Climate, Sustainability and Security Infrastructure (CEST) for providing some fundamental instruments installed in the urban flux tower. This paper contributes to BRIDGE Project (www.bridge-fp7.eu), funded by the European Commission. The authors would like to thank the anonymous reviewers for their valuable comments and suggestions to improve the quality of the paper.

\section{References}

Akbari, $\mathrm{H}$. (2002). Shade trees reduce building energy use and $\mathrm{CO}_{2}$ emissions from power plants. Environmental Pollution, 116, 119-126.

Aydin, M. B. S., \& Cukur, D. (2012). Maintaining the carbon-oxygen balance in residential areas: A method proposal for land use planning. Urban Forestry E' Urban Greening, 11(1), 87-94.

Baldocchi, D. (2003). Assessing the eddy covariance technique for evaluating carbon dioxide exchange rates of ecosystems: Past, present and future. Global Change Biology, 9, 479-492.

C40, ICLEI, World Resources Institute. (2012). Global protocol for community-scale greenhouse gas emissions. , http://www.ghgprotocol.org/ files/ghgp/GPC_PilotVersion_1.0_May2012_20120514.pdf

Ceschia, E., Béziat, P., Dejoux, J. F., Aubinet, M., Bernhofer, C. h., Bodson, B., et al. (2010). Management effects on net ecosystem carbon and GHG budgets at European crop sites. Agriculture. Ecosystems and Environment, 139, 363-383.

Chiesura, A. (2004). The role of urban parks for the sustainable city. Landscape and Urban Planning, 68(1), 129-138.

CIE (Center for International Earth Science Information Network). (2004). Global Rural-Urban Mapping Project (GRUMP) alpha version: Urban extents. http://sedac.ciesin.columbia.edu/gpw.

Conant, R. T., Paustian, K., \& Elliott, E. T. (2001). Grassland management and conversion into grassland: Effects on soil carbon. Applied Ecology, 11, 343-355.

CRA. (1980). Annali dell'Istituto Sperimentale per l'Assestamento Forestale $e$ per l'Alpicoltura, (Annals of the Institute for Experimental Forestry Management and Alpine farming, Agricultural Research Council). Consiglio per la Ricerca e la Sperimentazione in Agricoltura (CRA). http://mpf.entecra.it/files/annali/Volume6.pdf.

Crawford, B., Grimmond, C. S. B., \& Christen, A. (2011). Five years of carbon dioxide fluxes measurements in a highly vegetated suburban area. Atmospheric Environment, 45, 896-905.

Dhakal, S. (2010). GHG emissions from urbanization and opportunities for urban carbon mitigation. Current Opinion in Environmental Sustainability, 2, 277-283.

Dobbs, C., Escobedo, F., \& Zipperer, W. (2011). A framework for developing urban forest ecosystem services and goods indicators. Landscape and Urban Planning, 99, 196-206.

Duany, A., Speck, J., \& Lydon, M. (2009). The smart growth manual. New York: McGraw-Hill Professional.

EEA. (2007). EMEP/CORINAIR Emission Inventory Guidebook - 2007. In Technical report No. $16 / 2007$.

Escobedo, F., Varela, S., Zhao, M., Wagner, J., \& Zipperer, W. (2010). The efficacy of subtropical urban forests in offsetting carbon emissions from cities. Environmental Science and Policy, 13, 362-372.

Escobedo, F., Kroeger, T., \& Wagner, J. (2011). Urban forests and pollution mitigation: Analyzing ecosystem services and disservices. Environmental Pollution, 159, 2078-2087.

FAO. (2005). Global forest resources assessment update 2005: Italy pilot country report. In FAO working paper 76 . Roma.

Farr, D. (2007). Sustainable Urbanism: Urban design with nature. San Francisco: Wiley

Gidlöf-Gunnarsson, A., \& Öhrström, E. (2007). Noise and well-being in urban residential environments: The potential role of perceived availability to nearby green areas. Landscape and Urban Planning, 83(1-2), 115-126.

Gioli, B., Toscano, P., Lugato, E., Matese, A., Miglietta, F., Zaldei, A., et al. (2012) Methane and carbon dioxide fluxes and source partitioning in urban areas: The case study of Florence, Italy. Environmental Pollution, 164, 125-131.

Grimmond, C. S. B., King, T. S., Cropley, F. D., Nowak, D. J., \& Souch, C. (2002). Local-scale fluxes of carbon dioxide in urban environments: Methodological challenges and results from Chicago. Environmental Pollution, 116, 243-254.

Hartig, T. A., Evans, G. W., Jamner, L. D., Davis, D. S., \& Garling, T. (2003). Tracking restoration in natural and urban field settings. Journal of Environmental Psychology, 23, 109-123.

Helfter, C., Famulari, D., Phillips, G. J., Barlow, J. F., Wood, C. R., Grimmond, C. S. B., et al. (2011). Controls of carbon dioxide concentrations and fluxes above central London. Atmospheric Chemistry and Physics, 11, 1913-1928.

$\mathrm{Hu}$, Y., \& Gensuo, J. (2010). Influence of land use change on urban heat island derived from multi-sensor data. International Journal of Climatology, 30(9), 1382-1395. 
IPCC (International Panel on Climate Change). (2003). Good practice guidance for LULUCF (Land Use, Land Use Change and Forestry). , http://www.ipccnggip.iges.or.jp/public/gpglulucf/gpglulucf.html.

IPCC (International Panel on Climate Change). (2006). Guidelines for National Greenhouse Gas Inventories. AFOLU (Agriculture, Forestry and Other Land Use). , http://www.ipcc-nggip.iges.or.jp/public/2006gl/vol4.html.

IRSE. (2010). Regional Emission Inventory of the Tuscany Region. http://www.osservatoriokyoto.it/userfiles/file/irse.pdf (in@@ press).

Jo, H. K., \& McPherson, E. G. (1995). Carbon storage and flux in urban residential greenspace. Journal of Environmental Management, 45, 109-133.

Katz, P. (1994). New Urbanism. Towards an architecture of community. New York: McGraw-Hill.

Keenan, T. F., Baker, I., Barr, A., Ciais, P., Davis, K., Dietze, M., et al. (2012). Terrestrial biosphere model performance for inter-annual variability of land-atmosphere $\mathrm{CO}_{2}$ exchange. Global Change Biology, 18(6), 1971-1987.

Kennedy, C., Steinberger, J., Gasson, B., Hansens, Y., Hillman, T., Havranek, M., et al. (2010). Methodology for inventoring greenhouse gas emissions from global cities. Energy Policy, 38, 4828-4837.

Kordowski, K., \& Kuttler, W. (2010). Carbon dioxide fluxes over an urban park area. Atmospheric Environment, 44, 2722-2730.

Lin, W. Q., Wu, T. H., Zhang, C. G., \& Yu, T. (2011). Carbon savings resulting from the cooling effect of green areas: A case study in Beijing. Environmental Pollution, 159(8-9), 2148-2154.

Magno, R., Gioli, B., Vaccari, F. P., \& Canfora, E. (2010). Influence of water availability on carbon uptake of two Mediterranean Holm oak forests. Geophysical Research Abstracts, 12. EGU2010-12249-2, 2010 (http://adsabs.harvard.edu/abs/2010EGUGA.1212249M)

Matese, A., Alberti, G., Gioli, B., Toscano, P., Vaccari, F. P., \& Zaldei, A. (2008). Compact Eddy: A compact, low consumption remotely controlled eddy covariance logging system. Computers and Electronics in Agriculture, 64, 343-346.

Matese, A., Gioli, B., Vaccari, F. P., Zaldei, A., \& Miglietta, F. (2009). Carbon dioxide emissions of the city center of Firenze, Italy: Measurement, evaluation, and source partitioning. Journal of Applied Meteorology and Climatology, 48(9), 1940-1947.

McHale, M. R., McPherson, E. G., \& Burke, I. C. (2007). The potential of urban tree plantings to be cost effective in carbon credit markets. Urban Forestry and Urban Greening, 6, 49-60.

Mirzaei, P. A., \& Haghighat, F. (2010). Approaches to study urban heat island. Abilities and limitations. Building and Environment, 45, 2192-2201.

Morani, A., Nowak, D. J., Hirabayashi, S., \& Calfapietra, C. (2011). How to select the best tree planting locations to enhance air pollution removal in the Million Trees NYC initiative. Environmental Pollution, 159, 1040-1047.

Mostafavi, M., \& Doherty, G. (2010). Ecological Urbanism. Boston: Harvard University.

Ng, E., Chen, L., Wang, Y., \& Yuan, C. (2012). A study on the cooling effects of greening in a high-density city: An experience from Hong Kong. Building and Environment, $47,256-271$.

Nowak, D. J., \& Crane, D. E. (2002). Carbon storage and sequestration by urban trees in the USA. Environmental Pollution, 116, 381-389.

Nowak, D. J., Crane, D. E., \& Stevens, J. C. (2006). Air pollution removal by urban trees and shrubs in the United States. Urban Forest \& Urban Greening, 4, 115-123.

Odum, E. P. (1971). Fundamentals of ecology (3rd ed.). Philadelphia, London, Toronto: W.B. Saunders Company.

Oliveira, S., Andrade, H., \& Vaz, T. (2011). The cooling effect of green spaces as a contribution to the mitigation of urban heat: A case study in Lisbon. Building and Environment, 46, 2186-2194.

Onishi, A., Cao, X., Ito, T., Shi, F., \& Imura, H. (2010). Evaluating the potential for urban heat-island mitigation by greening parking lots. Urban Forestry E Urban Greening, 9(4), 323-332.

Paoletti, E., Bardelli, T., Giovannini, G., \& Pecchioli, L. (2011). Air quality impact of an urban park over time. Procedia Environmental Sciences, 4, 10-16.

Pataki, D. E., Emmi, P. C., Forster, C. B., Mills, J. I., Pardyjak, E. R., Peterson, T. R., et al. (2009). An integrated approach to improving fossil fuel emissions scenarios with urban ecosystem studies. Ecological Complexity, 6, 1-14.

Pataki, D. E., Carreiro, M. M., Cherrier, J., Grulke, N. E., Jennings, V., Pincetl, S., et al. (2011). Coupling biogeochemical cycles in urban environments: Ecosystem services, green solutions, and misconceptions. Frontiers Ecology Environment, 9, $27-36$.

Pawlak, W., Fortuniak, K., \& Siedlecki, M. (2010). Carbon dioxide flux in the centre of Lodz, Poland analysis of a 2-year eddy covariance measurement data set. International Journal of Climatology, 31, 232-243.

Petralli, M., Massetti, L., \& Orlandini, S. (2011). Five years of thermal intra-urban monitoring in Florence (Italy) and application of climatological indices. Theoretical and Applied Climatology, 104(4), 349-356

Qian, Y., \& Follett, R. F. (2002). Assessing soil carbon sequestration in turfgrass systems using long-term soil testing data. Agronomy Journal, 94, 930-935.

Reckien, D., Ewald, M., Edenhofer, O., \& Ludeke, M. K. B. (2007). What parameters influence the spatial variations in $\mathrm{CO}_{2}$ emissions from road traffic in Berlin? Implications for urban planning to reduce anthropogenic $\mathrm{CO}_{2}$ emissions. Urban Studies, 44, 339-355.
Salvati, L., Munafo, M., Gargiulo Morelli, V., \& Sabbi, A. (2012). Low-density settlements and land use changes in a Mediterranean urban region. Landscape and Urban Planning, 105, 43-52.

Schneider, A., \& Woodcock, C. E. (2008). Compact, dispersed, fragmented, extensive? A comparison of urban growth in twenty-five global cities using remotely sensed data, pattern metrics and census information. Urban Studies, 45(3), 659-692.

Sofo, A., Nuzzo, V., Palese, A. M., Xiloyannis, C., Celano, G., Zukowskyj, P., et al. (2005). Net $\mathrm{CO}_{2}$ storage in Mediterranean olive and peach orchards. Scientic Horticulturae, 107, 17-24.

Sproken-Smith, R. A., \& Oke, T. (1998). The thermal regime of urban parks in two cities with different summer climates. International Journal of Remote Sensing, 19, 2085-2104.

Steeneveld, G. J., Koopmans, S., Heusinkveld, B. G., vanHove, L. W. A., \& Holtslag, A A. M. (2011). Quantifying urban heat island effects and human comfort for cities of variable size and urban morphology in the Netherlands. Journal of Geophysical Research Atmospheres, 116 http://dx.doi.org/10.1029/2011JD015988, article number: D20129

Tallis, M., Taylor, G., Sinnett, D., \& Freer-Smith, P. (2011). Estimating the removal of atmospheric particulate pollution by the urban tree canopy of London, under current and future environments. Landscape and Urban Planning, 103, 129-138.

Upmanis, H., \& Chen, D. (1999). Influence of geographical factors and meteorological variables on nocturnal urban-park temperature differences-a case study of summer 1995 in Goteborg, Sweden. Climate Research, 13, 125-139.

Velasco, E., \& Roth, M. (2010). Cities as net sources of $\mathrm{CO}_{2}$ : Review of atmospheric $\mathrm{CO}_{2}$ exchange in urban environments measured by eddy covariance technique. Geography Compass, 4(9), 1238-1259.

Waldheim, C. E. (2006). Landscape Urbanism reader. New York: Princeton Architectural Press.

Zhao, M., Kong, Z., Escobedo, F., \& Gao, J. (2010). Impacts of urban forests on offsetting carbon emissions from industrial energy consumption for Hangzhou, China. Journal of Environmental Management, 91(4), 807-813.

Zirkle, G., Lal, R., Augustin, B., \& Follett, R. (2012). Modeling carbon sequestration in the U.S. residential landscape. In R. Lal, \& B. Augustin (Eds.), Carbon sequestration in urban ecosystems (pp. 265-276) http://dx.doi.org/10.1007/978-94-007-2366-5_14. ISBN 978-94-007-2365-8

Perrone (1970), Architect, PhD on Urban, Landscape and Environmental Design (2002), is currently assistant professor on Urban and Regional Planning at Department of Urban and Regional Planning-University of Florence. She has jus concluded a semester as visiting professor (full position) on Urban and Regiona Planning and Participatory Planning, at Institute of Geography (Geographisches Institut)-University of Tübingen. She collaborates with some international research networks, such as Aesop (Association of European Schools of Planning) within which she is national (Italy) representative (as alternate member). She has published numerous academic articles and has contributed chapters to several publications on urban policies for managing diversity, urban and regional planning with regard to land consumption containment, urban-rural fringe re-design, public space redesign, local development policies and planning tools, participatory planning.

Vaccari (1967), Agricultural Science degree in 1994, PhD in Ecology and Environmental Systems. Research scientist at the Institute of Biometeorology Nationa Research Council, since 2002. Scientific interests and highlights: Effects of high CO2 on crops and natural ecosystems; Biosphere atmosphere interactions; Urban carbon fluxes; Precision agriculture; Biochar. He has 36 peer reviewed papers, h-index $=11$.

Gioli (1971), Environmental Engineering degree in 1998. PhD in Ecology and Environmental Systems. Advanced research scientist at the Institute of Biometeorology National Research Council, since 2004. Major scientific results: Development and extensive validation of the aircraft flux measurements methodology; Development of upscale methods to derive regional scale carbon balance; Using regional fluxes as a validation toll for atmospheric and ecosystem modeling: Study of interactions between surface and PBL fluxes. He has 36 peer reviewed papers, h-index $=11$.

Toscano (1980), Sciences and technology (Oceanography and Meteorology) degree in 2005. Master in Applied Meteorology in 2006. PhD student in Ecology and Environmental Systems. Excellent experience gained during many national and international campaign, planning and operating data acquisition of research aircraft that had to be operated in synergy with several other aircrafts and extensive ground activities (atmospheric measurements, carbon dioxide fluxes, boundary layer characterization, environmental pollution sampling, remote sensing). Excellent experience gained during national and international shipboard missions (morpho-bathymetry, biostratigraphy, oceanographic sampling, carbon dioxide and acetone air-sea fluxes measurements). Experience in remote sensing techniques, instruments and applications with optical data gained in the last five years of work experience. Experience on satellite data products, processing and final applications. Management of meteorological and micro-meteorological instrumentations, data acquisition, analysis and data processing. Crop modeling, experimental and modeling durum wheat growth stages, quality and vulnerable developmental stages. Current position: Research scientist at the Institute of Biometeorology National Research Council. He has 9 peer reviewed papers, h-index $=4$. 